\title{
Report \\ Restoration of Midwest Oak Barrens: Structural Manipulation or Process-only?
}

\author{
$\underline{\text { Scott Nielsen }}^{1}$, Chad Kirschbaum $^{2}$, and Alan Haney $^{3}$
}

\begin{abstract}
We investigated vegetation responses in terms of canopy, ground-layer diversity, and ecological species groups using two restoration treatments at two degraded oak barren and savanna sites in central Wisconsin, USA. The two restoration models tested were (1) process-only, which reintroduced fire in the form of prescribed burning, and (2) structural manipulation, which used prescribed burning following selective timber removal. Both methods have been widely promoted, debated, and investigated in the fire-prone ecosystems of western North America, but they have not been studied in midwestern ecosystems. Vegetation was monitored in permanent quadrats prior to and following treatment applications. All treatment responses were compared against trends at control sites. We used diversity, canopy, and cover estimates within ecological groups between pre- and post-treatment periods as our response. Effect size was calculated, and the statistical significance of effects was determined using one-factor analysis of variance. Following treatments, canopy levels were restored to prior savanna levels with structural manipulation, but failed to respond to process-only approaches. Likewise, multiple positive responses were detected in the ground layer with structural manipulation, but few with process-only treatments. Despite initial responses, ground-layer restoration appears to be constrained by the dominance of Pennsylvania sedge (Carex pensylvanica). Many savanna forbs, legumes, and $\mathrm{C}_{4}$ graminoids were missing. We presume that $70 \mathrm{yr}$ of fire suppression and associated succession to oak woodlands were largely responsible for sedge conversion and the loss of savanna species. Despite observed limitations, structural manipulation treatments appeared to be more effective than process-only approaches. Sites with holdover savanna species that have not been dominated by sedge should be targeted for immediate restoration before further losses occur. Further investigation of sedge mat thresholds and long-term restoration dynamics is required.
\end{abstract}

\section{INTRODUCTION}

Savannas form one of the most widespread and socioecologically important ecosystems of the world (Werner et al. 1990). Prior to Anglo-European settlement, North America contained some $50 \times 10^{6}$ ha of savanna (McPherson 1997), of which the most extensive was the midwestern oak savanna that stretched from Texas to Manitoba and covered some $11-13 \times 10^{6}$ ha (Nuzzo 1986). Today, only about 2600 ha $(0.02 \%)$ of high-quality midwest oak savanna remain (Nuzzo 1986). Most remnants are dry, nutrientpoor sites typically referred to as oak barrens (Heikens and Robertson 1994), which have escaped agricultural development and extensive woody encroachment (Abrams 1992). Structurally, these remnants are characterized by the presence of oak grubs from either Hill's oak (Quercus ellipsoidalis) or black oak ( $Q$. velutina) and by a diverse ground layer of forbs, $\mathrm{C}_{3}$ and $\mathrm{C}_{4}$ graminoids, and legumes (Curtis 1959). Most scientists agree that the structure and composition of the oak barrens were maintained through frequent disturbances, primarily by fire (Abrams 1992). Fire suppression, which began in earnest during the 1930s, resulted in the development of even-aged oak woodlands and forests throughout much of the region (Fig. 1). One result of this was the loss of important focal species, including sharp-tailed grouse (Pedioecetes phasianellus), the Karner blue butterfly (Lycaeides melissa samuelis), and numerous forbs, graminoids, and legumes. In recent years, restoration has been a high priority, especially with the designation of the Karner blue butterfly as endangered.

Most scientists agree that simply reintroducing the primary natural process, fire, after manipulating the canopy structure through timber removal in some cases, will lead to restoration (Vogl 1964, Holtz and Howell 1983, White 1983). For instance, Vogl (1964) described the reappearance of 41 prairie and savanna species within

${ }^{1}$ University of Alberta; ${ }^{2}$ University of Michigan; ${ }^{3}$ University of Wisconsin-Stevens Point 
a year of a prescribed burn in a 35-yr-old degraded oak barren in northwest Wisconsin, calling this phenomenon an "instantaneous prairie response." Similar responses were observed at the Leopold Memorial Reserve in central Wisconsin some decades later. Timber removal and prescribed burning here resulted in the reappearance of 52 and 78 ground-layer species within 1 and $5 \mathrm{yr}$, respectively (Holt and Howell 1983). Although these sites appeared to be in an alternate steady-state condition of oak woodland/forest prior to restoration, rapid responses pointed to the extraordinary ecological resilience of the ecosystem. However, Vogl (1964) speculated that many holdover savanna and prairie species would eventually be eliminated as barrens succeeded to forests, and residual corms, roots, and rhizomes disappeared.

Fig. 1. Two photographs from Rabbit Rock, Adams County, Wisconsin, USA, that depict the transition from oak barren to degraded oak woodland over $150 \mathrm{yr}$. The historic photograph (A), which was taken in about 1850 , represents a healthy oak barren with scattered oak grubs within a matrix of graminoids. Following $70 \mathrm{yr}$ of fire suppression (B), the oak grubs have succeeded to coppiced oak trees with a ground layer dominated by Carex pensylvanica. Note the dominant outcrop in the upper left corner of each photograph for reference; the scale and angle differ slightly in each picture.
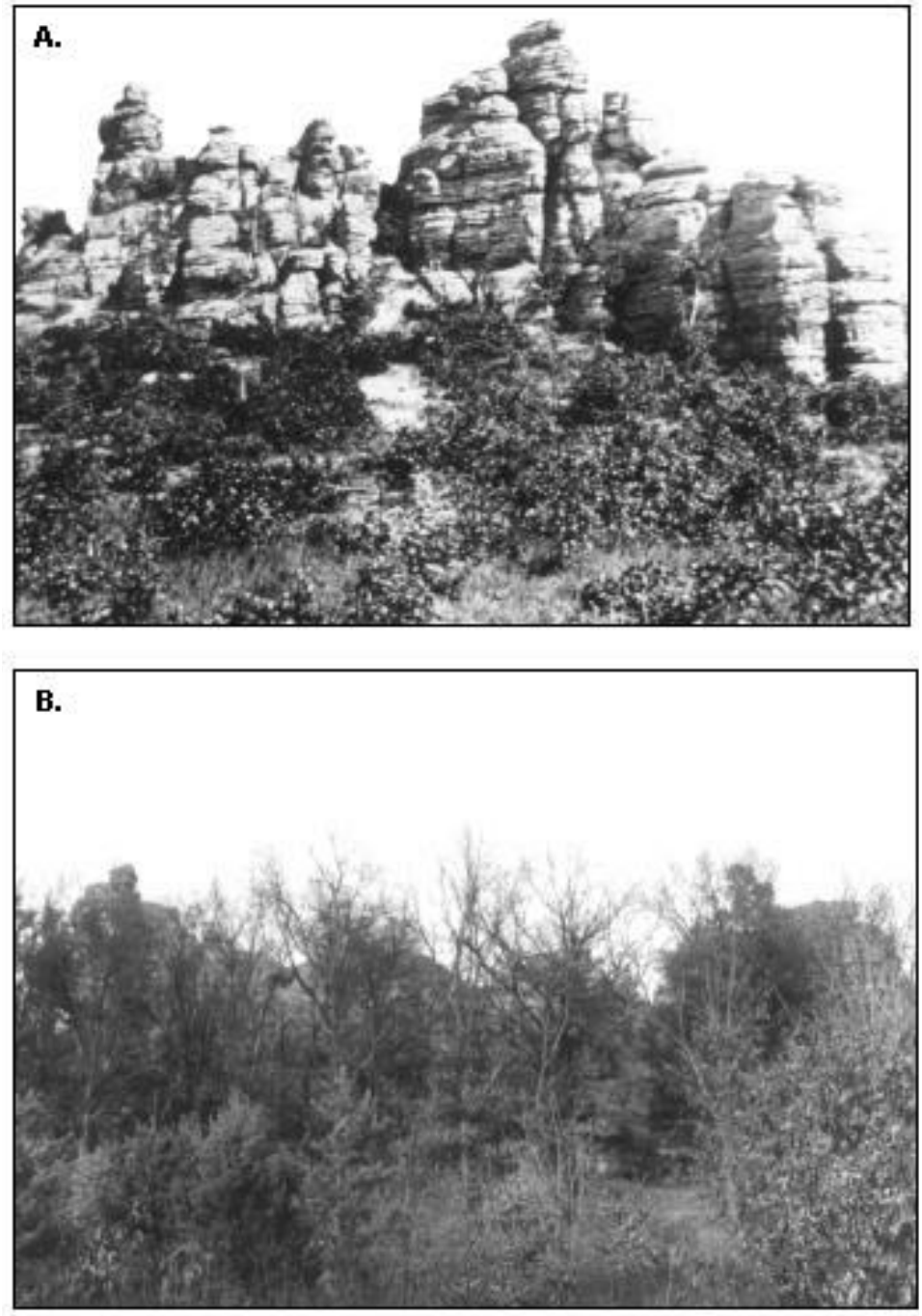

Despite increasing efforts to restore degraded oak barren sites, there is currently a lack of quantitative data on restoration responses. Here we test two models that have already been considered for the restoration of fire-prone forest ecosystems in western North America. The first method is simply the reintroduction of fire through prescribed burning. This process-only approach assumes that the initial structure is of little 
importance and that degraded fire-prone ecosystems are probably already within their natural range of variability (e.g., Parsons et al. 1986, Stephenson 1999). Thus, the return of natural processes alone should be sufficient for the restoration of structure, composition, and function. In comparison, the second method involves the initial removal of selected trees followed by the reintroduction of fire. This restoration model, referred to as the "structural manipulation approach," hinges on the assumption that the reconstruction of the structure of the ecosystem will help facilitate the recovery of its dynamics and selfregulatory processes (Bonnicksen and Stone 1985, Moore et al. 1999). The structural manipulation approach does not deny the importance of fire; it simply assumes that structural modifications will hasten recovery (Bowles and McBride 1998).

Our paper summarizes the results of a study that monitored the effects of restoration treatments at two degraded oak barrens in central Wisconsin, USA. Our objectives were (1) to evaluate the success of the process-only approach and the structural manipulation approach when compared to controls and (2) to address whether the "instantaneous" responses previously observed in the literature could still be obtained at sites that have been degraded for well over $50 \mathrm{yr}$. Is it possible that we have crossed an ecological threshold that prevents rapid-response restoration through structural manipulation and/or the reintroduction of natural processes?

Fig. 2. Map of the study area showing the location of historic barrens, counties, and study sites within Wisconsin. A is the Necedah National Wildlife Refuge, and B is the Quincy Bluff and Wetland Natural Area. The map inset shows the location of this region within North America.

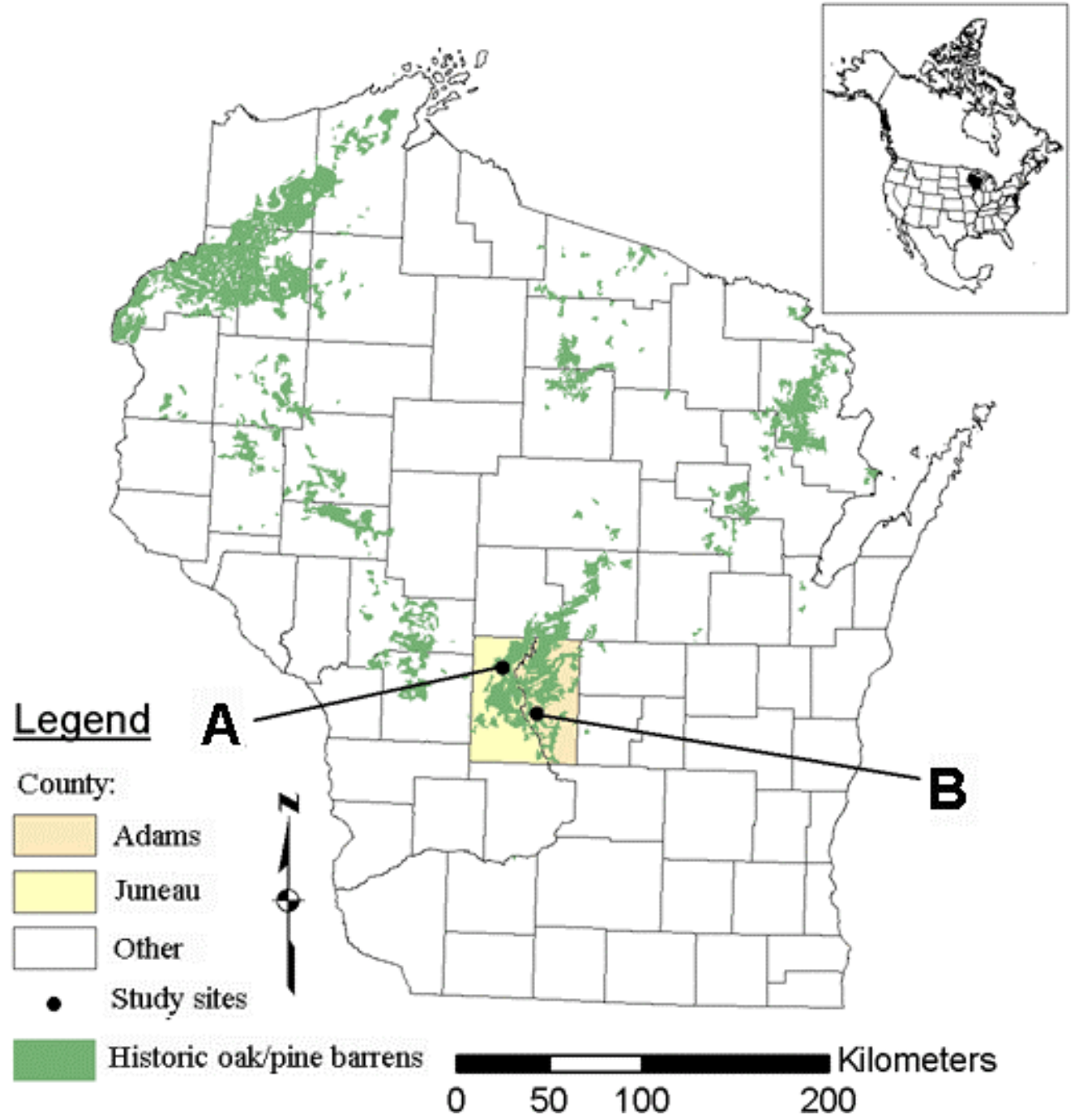




\section{METHODS}

\section{Study areas}

Our research was conducted at the Necedah National Wildlife Refuge $\left(44^{\circ} 00^{\prime} \mathrm{N}, 90^{\circ} 00^{\prime} \mathrm{W}\right)$ and the Quincy Bluff and Wetlands State Natural Area $\left(43^{\circ}\right.$ $45^{\prime} \mathrm{N}, 89^{\circ} 30^{\prime} \mathrm{W}$ ) in central Wisconsin (Fig. 2). Both areas lie within the basin of proglacial Lake Wisconsin and are characterized by extensive dry deposits of glacial outwash sands and shallow wet depressions. Sedge meadows and conifer swamps predominate in the low depressions, and oak barrens and woodlands are common in the upland sandy areas (Jakel 1980, Gundlach et al. 1991, Albert 1994). The climate is continental, with an average annual temperature of $7.2^{\circ} \mathrm{C}$ and an average annual precipitation of $801 \mathrm{~mm}$. Established in 1939, the Necedah National Wildlife Refuge, hereafter referred to as Necedah, represents a 17,667-ha landscape of wetlands, managed pools, oak forests, and the scattered remnants of oak barrens in northern Juneau County, Wisconsin (U.S. Fish and Wildlife Service 2000). After the refuge was established, fire suppression began in earnest, resulting in the replacement of open oak barrens by even-aged oak woodlands. In 1992, the refuge began a program of oak barrens restoration. Necedah's primary approach to restoration has been structural manipulation, in which the overstory structure is first modified by selective timber removals and fire is then returned via prescribed burning. To date, 695 ha have undergone restoration treatments, with an additional 1052 ha scheduled for restoration in the first decade of the 21 st century (U.S. Fish and Wildlife Service 2000).

The Quincy Bluff and Wetlands State Natural Area, hereafter referred to as Quincy, covers more than 1200 ha of lake plain and outwash soils characterized by a rich mosaic of sedge meadows, conifer swamps, and oak and jack pine barrens in eastern Adams County, Wisconsin. The Nature Conservancy (TNC) and the Wisconsin Department of Natural Resources cooperatively manage the site. Dominating the landscape of the TNC property is Quincy Bluff, a single large outcrop of Cambrian sandstone that measures $3.5 \mathrm{~km}$ from north to south, 0.5 $\mathrm{km}$ from east to west, and $75 \mathrm{~m}$ in height. Along the western flank of this bluff lies an area of sandy Plainfield-Friendship soil and closely associated degraded oak barrens. Restoration of these degraded oak barrens has been going on since 1993, when prescribed fires were first introduced. The primary method used to restore the barrens at Quincy has been the application of repeated prescribed fires, i.e., the process-only approach.
Limited restoration units have been treated using methods of structural manipulation.

\section{Experimental design and monitoring}

Between 1991 and 1994, 52 long-term permanent vegetation transects were established at Quincy $(n=$ $30)$ and Necedah $(n=22)$. Vegetation characteristics were measured on each transect prior to treatment application. In 1999, the same transects were remonitored following the application of restoration treatments. Vegetation transects consisted of 50-m lines randomly located within stratified restoration units. Along each transect, percent vascular groundlayer cover, by species, was estimated at $10-\mathrm{m}$ intervals using $1-\mathrm{m}^{2}$ circular quadrats (Haney and Apfelbaum 1994). Canopy was measured above the same transects using a line intercept estimate (Canfield 1941, Bauer 1943). This method used an imaginary vertical plane projected above transect tapes to intercept tree canopies. Taxonomy follows that of Gleason and Cronquist (1991).

Three separate restoration treatments were tested: (1) neither process-only nor structural manipulation, i.e., the control; (2) prescribed burning only, known as the process-only model; and (3) the combination of selective timber removal and prescribed fire, called the structural manipulation model. At Necedah, trees $>38 \mathrm{~cm} \mathrm{dbh}$ (diameter at breast height) were selectively harvested at two restoration units on degraded oak barrens during the winters of 1996, 1997, and 1998. Following harvest, both restoration units were treated with prescribed fire in the springs of 1998 and 1999. No process-only treatments were applied at Necedah. At Quincy, four restoration units were treated using the process-only approach between 1993 and 1999. Respectively, the process-only units received two, three, five, and seven spring burns over the course of these seven years. The structural manipulation model was applied to a single restoration unit at Quincy. This unit received six treatments of prescribed fire and a selective timber removal treatment during the winters of 1996 and 1997. In contrast to Necedah's dbh threshold for selective timber removal, Quincy used a more subjective approach by removing most of the "small" trees, but keeping a few for future recruitment and/or for species preferences. All control transects, which were degraded oak barrens, were located within similar soils and topographic areas near treatment sites.

Pretreatment data were collected at Quincy in June of 1991 and 1994 and at Necedah in June of 1994. In 
June of 1999, following the implementation of treatments, post-treatment data were collected along permanent transects. Because of initial differences in floristic composition, the analyses from Necedah and Quincy were separated. Here we test the null hypothesis $\left(\mathrm{H}_{0}\right)$ that restoration treatments had no significant effect on ground-layer richness, diversity, evenness, or cover for $\mathrm{C}_{3}$ grasses, $\mathrm{C}_{4}$ grasses, forbs, legumes, and modal savanna or prairie species groups when compared to controls.

\section{Ecological response variables}

We evaluated the effect of barrens restoration on canopy intercept and three separate sets of ecological response variables. The first set of ecological variables concerned the ways in which restoration affected species number relationships, specifically that of ground-layer diversity. Three measures of diversity were used, namely, species richness $(R)$, evenness $(J)$, and diversity $(H)$. Evenness and diversity were calculated using the Shannon-Wiener index (Shannon and Weaver 1949) from Magurran (1988). Our second set of ecological variables involved the cover of functional life-form groups, including forbs, legumes, $\mathrm{C}_{3}$ grasses, $\mathrm{C}_{4}$ grasses, sedges, ferns, vines, shrubs, and trees (Appendix 1). Finally, we tested the cover of the modal species groups, i.e., the native community in which a species achieved its highest presence, defined in Curtis (1959). However, we simplified the 34 native communities of Wisconsin in which modal species occurred to four basic ecosystems: grassland, savanna, southern forest, and northern forest. All measurements were made at the transect level to avoid spatial autocorrelation and pseudoreplication among quadrats (Hurlburt 1984).

\section{Data analysis}

To test for treatment effects on each ecological response variable, we examined changes (temporal trends) in cover between pre- and post-treatment periods for each response variable (Appendix 1). Positive values indicated an increase and negative values a decrease in the amount of cover between preand post-treatment sampling. By using temporal trend data, we avoided the limitations associated with repeated-measures analysis-of-variance designs in which treatment and time interactions can bias results (Underwood 1997). To make valid statements of trends, we compared all temporal treatment effects against control treatments, thereby removing natural trends associated with environmental fluctuations (Gram et al. 2001).
For each response variable, we calculated an unbiased estimate of effect size $\left(d_{j}\right)$ and $95 \%$ confidence intervals for treatment and control groups. Effect size, following that of Hedges and Olkin (1981) and Gram et al. (2001), was defined as

$$
d_{j}=\frac{M_{T}-M_{\mathrm{C}}}{S D_{T C}}
$$

where $M_{T}$ is the difference between response values for pretreatment and post-treatment periods in transects in both the process-only and structural manipulation treatments, $M_{C}$ is the difference between response values for pretreatment and post-treatment periods for control transects, $S D_{T C}$ is the pooled standard deviation of differences for control and treatment plots, and $j$ represents the ecological variable measured.

To test our null hypotheses, we compared pre- and post-treatment trends on control sites to trends on treatment sites using a one-factor analysis of variance (ANOVA). The fixed factor in the ANOVA models was the treatment, with structural manipulation or process-only treatments compared to controls. A Bartlett's test of unequal variances was used to inspect assumptions of homogeneity of variance between populations. All ANOVAs were performed with STATA version 7.0 using the procedure ONEWAY. Significance values for all tests were considered at the $P>0.05$ level. However, given the potential pseudoreplication of transects within management units, interpretation of significance should be viewed in a biological, rather than a statistical, manner.

\section{RESULTS}

\section{Structural manipulation}

Significantly negative responses were observed for canopy intercept following treatments at Necedah $\left(d_{j}=\right.$ -1.97, $F_{1,20}=21.18, P>0.001$; Table 1$)$ and Quincy $\left(d_{j}\right.$ $=-1.66, F_{1,8}=8.60, P=0.019$; Table 2 ). Together with prescribed burning, these restoration treatments resulted in increases in species richness at Necedah $\left(d_{j}\right.$ $\left.=0.92, F_{1,20}=5.04, P=0.036\right)$ and especially Quincy $\left(d_{j}=3.05, F_{1,8}=28.54, P>0.001\right)$. Diversity $\left(H^{\prime}\right)$ and evenness $(J)$ responses were similar to that of species richness. Functional groups that responded positively to the structural manipulation model included $\mathrm{C}_{3}$ grass $\left(d_{j}=1.40, F_{1,20}=11.63, P=0.003\right)$ and fern cover $\left(d_{j}\right.$ $\left.=1.27, F_{1,20}=6.39, P=0.020\right)$ at Necedah and forb cover $\left(d_{j}=1.59, F_{1,8}=7.79, P=0.024\right)$ at Quincy. The 
main fern species to respond was bracken-fern (Pteridium aquilinum). Although we hypothesized that $\mathrm{C}_{4}$ grasses and legumes would increase following restoration, we found no evidence of significant trends. For modal groups at Quincy, we found significant positive responses for grassland species $\left(d_{j}=1.77, F_{1,8}\right.$ $=9.60, P=0.015)$ and marginally significant positive effects for modal savanna species $\left(d_{j}=1.25, F_{1,8}=\right.$
4.80, $P=0.060)$. At Necedah, marginally significant positive responses were again evident for grassland $\left(d_{j}\right.$ $\left.=0.84, F_{1,20}=4.19, P=0.054\right)$ and savanna $\left(d_{j}=0.70\right.$, $\left.F_{1,20}=2.86, P=0.106\right)$ modal groups. Southern and northern forest species did not appear to vary between treatment periods. Domination by Carex pensylvanica, especially at Necedah, was evident prior to and following treatment application (Fig. 3).

Table 1. Structural manipulation trends differences (mean $\pm \mathrm{SD}$ ) for pre- to post-treatment ecological group measures at Necedah National Wildlife Refuge. Bias-adjusted effect size, 95\% confidence interval of effect size, and $F$-values and probabilities for analysis-of-variance (ANOVA) tests are reported. ANOVA models tested main effects of the structural manipulation treatment $(n=12)$ against the control $(n=10)$. Significance values of tests are indicated in bold at $P<0.05$, whereas marginal significance values $(P<0.10)$ are in italics.

\begin{tabular}{|c|c|c|c|c|c|c|c|}
\hline \multirow[t]{2}{*}{ Ecological group } & \multirow{2}{*}{$\begin{array}{l}\text { Control } \\
\text { plot }\end{array}$} & \multirow{2}{*}{$\begin{array}{l}\text { Treatment } \\
\text { plot }\end{array}$} & \multirow{2}{*}{$\begin{array}{l}\text { Effect } \\
\text { size }\end{array}$} & \multicolumn{2}{|c|}{$95 \% \mathrm{CI}$} & \multicolumn{2}{|c|}{ ANOVA } \\
\hline & & & & Lower & Upper & $F$ & $P$ \\
\hline Canopy intercept & $\begin{array}{c}-4.16 \\
( \pm 15.04)\end{array}$ & $\begin{array}{l}-62.14 \\
( \pm 36.89)\end{array}$ & -1.97 & -3.04 & -0.90 & 21.18 & $<0.001$ \\
\hline Species richness & $\begin{array}{c}-1.92 \\
( \pm 3.23)\end{array}$ & $\begin{array}{c}0.90 \\
( \pm 2.51)\end{array}$ & 0.92 & 0.04 & 1.81 & 5.04 & 0.036 \\
\hline Diversity & $\begin{array}{c}-0.54 \\
( \pm 0.49)\end{array}$ & $\begin{array}{c}0.66 \\
( \pm 0.95)\end{array}$ & 1.58 & 0.62 & 2.54 & 14.69 & 0.001 \\
\hline Evenness & $\begin{array}{c}-0.14 \\
( \pm 0.18)\end{array}$ & $\begin{array}{c}0.22 \\
( \pm 0.31)\end{array}$ & 1.45 & 0.50 & 2.39 & 12.35 & 0.002 \\
\hline Modal savanna & $\begin{array}{c}3.73 \\
( \pm 7.16)\end{array}$ & $\begin{array}{c}8.06 \\
( \pm 4.10)\end{array}$ & 0.70 & -0.17 & 1.56 & 2.86 & 0.106 \\
\hline $\begin{array}{l}\text { Modal southern } \\
\text { forest }\end{array}$ & $\begin{array}{c}16.43 \\
( \pm 12.90)\end{array}$ & $\begin{array}{c}13.78 \\
( \pm 28.50)\end{array}$ & -0.12 & -0.96 & 0.72 & 0.08 & 0.775 \\
\hline $\begin{array}{l}\text { Modal northern } \\
\text { forest }\end{array}$ & $\begin{array}{c}-1.92 \\
( \pm 6.37)\end{array}$ & $\begin{array}{c}-0.54 \\
( \pm 3.60)\end{array}$ & 0.25 & -0.59 & 1.09 & 0.37 & 0.551 \\
\hline Modal grassland & $\begin{array}{c}0.17 \\
( \pm 6.50)\end{array}$ & $\begin{array}{c}6.62 \\
( \pm 8.30)\end{array}$ & 0.84 & -0.03 & 1.72 & 4.19 & 0.054 \\
\hline Forbs & $\begin{array}{c}-0.58 \\
( \pm 3.14)\end{array}$ & $\begin{array}{c}1.36 \\
( \pm 4.63)\end{array}$ & 0.48 & -0.37 & 1.33 & 1.37 & 0.256 \\
\hline $\mathrm{C}_{3}$ grasses & $\begin{array}{c}0.73 \\
( \pm 2.75)\end{array}$ & $\begin{array}{c}13.28 \\
( \pm 12.44)\end{array}$ & 0.87 & -0.01 & 1.74 & 11.63 & 0.003 \\
\hline $\mathrm{C}_{4}$ grasses & $\begin{array}{c}-0.22 \\
( \pm 1.66)\end{array}$ & $\begin{array}{c}0.52 \\
( \pm 0.98)\end{array}$ & 0.51 & -0.34 & 1.36 & 1.53 & 0.230 \\
\hline Sedges & $\begin{array}{c}17.63 \\
( \pm 13.34)\end{array}$ & $\begin{array}{c}13.90 \\
( \pm 28.00)\end{array}$ & -0.17 & -1.01 & 0.67 & 0.17 & 0.686 \\
\hline
\end{tabular}




\begin{tabular}{|c|c|c|c|c|c|c|c|}
\hline Shrubs & $\begin{array}{c}-0.57 \\
( \pm 6.16)\end{array}$ & $\begin{array}{c}2.16 \\
( \pm 4.90)\end{array}$ & 0.47 & -0.38 & 1.32 & 1.28 & 0.271 \\
\hline Ferns & $\begin{array}{c}-0.70 \\
( \pm 0.73)\end{array}$ & $\begin{array}{c}2.68 \\
( \pm 3.73)\end{array}$ & 1.27 & 0.35 & 2.19 & 6.39 & 0.020 \\
\hline Trees & $\begin{array}{c}2.02 \\
( \pm 7.17)\end{array}$ & $\begin{array}{c}3.36 \\
( \pm 3.29)\end{array}$ & 0.22 & -0.62 & 1.07 & 0.30 & 0.592 \\
\hline Legume & $\begin{array}{c}0.05 \\
( \pm 2.22)\end{array}$ & $\begin{array}{c}0 \\
( \pm 0)\end{array}$ & -0.03 & -0.87 & 0.81 & 0.01 & 0.944 \\
\hline Vines & $\begin{array}{c}0 \\
( \pm 0)\end{array}$ & $\begin{array}{c}0 \\
( \pm 0)\end{array}$ & 0 & 0 & 0 & 0 & 0 \\
\hline
\end{tabular}

Table 2. Structural manipulation trends differences (mean $\pm \mathrm{SD}$ ) for pre- to post-treatment ecological group measures at Quincy Bluff and Wetlands Natural Area. Bias-adjusted effect size, 95\% confidence interval of effect size, and $F$-values and probabilities for analysis-of-variance (ANOVA) tests are reported. ANOVA models tested main effects of the structural manipulationtreatment $(n=12)$ against the control $(n=10)$. Significance values of the tests are indicated in bold at $P<0.05$, whereas values for marginal significance $(P<0.10)$ are in italics.

\begin{tabular}{|c|c|c|c|c|c|c|c|}
\hline \multirow[t]{2}{*}{ Ecological group } & \multirow{2}{*}{$\begin{array}{c}\text { Control } \\
\text { plot }\end{array}$} & \multirow{2}{*}{$\begin{array}{c}\text { Treatment } \\
\text { plot }\end{array}$} & \multirow{2}{*}{$\begin{array}{c}\text { Effect } \\
\text { size }\end{array}$} & \multicolumn{2}{|c|}{$95 \% \mathrm{CI}$} & \multicolumn{2}{|c|}{ ANOVA } \\
\hline & & & & Lower & Upper & $F$ & $P$ \\
\hline Canopy intercept & $\begin{array}{c}-0.04 \\
( \pm 24.25)\end{array}$ & $\begin{array}{c}-52.92 \\
( \pm 32.22)\end{array}$ & -1.66 & -3.10 & -0.22 & 8.60 & 0.019 \\
\hline Species richness & $\begin{array}{c}-1.40 \\
( \pm 1.67)\end{array}$ & $\begin{array}{c}5.40 \\
( \pm 2.30)\end{array}$ & 3.05 & 1.23 & 4.87 & 28.54 & $<0.001$ \\
\hline Diversity & $\begin{array}{c}-0.76 \\
( \pm 0.58)\end{array}$ & $\begin{array}{c}1.24 \\
( \pm 0.33)\end{array}$ & 3.82 & 1.73 & 5.90 & 44.68 & $<0.001$ \\
\hline Evenness & $\begin{array}{c}-0.22 \\
( \pm 0.20)\end{array}$ & $\begin{array}{c}0.28 \\
( \pm 0.15)\end{array}$ & 2.55 & 0.88 & 4.22 & 20.03 & 0.002 \\
\hline Modal savanna & $\begin{array}{c}-0.48 \\
( \pm 4.19)\end{array}$ & $\begin{array}{c}12.12 \\
( \pm 12.16)\end{array}$ & 1.25 & -0.10 & 2.61 & 4.80 & 0.060 \\
\hline $\begin{array}{l}\text { Modal southern } \\
\text { forest }\end{array}$ & $\begin{array}{c}7.32 \\
( \pm 16.29)\end{array}$ & $\begin{array}{c}-0.64 \\
( \pm 15.37)\end{array}$ & -0.41 & -1.71 & 0.80 & 0.63 & 0.450 \\
\hline $\begin{array}{l}\text { Modal northern } \\
\text { forest }\end{array}$ & $\begin{array}{c}1.72 \\
( \pm 0.99)\end{array}$ & $\begin{array}{c}1.00 \\
( \pm 2.24)\end{array}$ & -0.38 & -1.63 & 0.87 & 0.43 & 0.529 \\
\hline Modal grassland & $\begin{array}{l}-9.08 \\
( \pm 8.77)\end{array}$ & $\begin{array}{c}6.48 \\
( \pm 7.01)\end{array}$ & 1.77 & 0.31 & 3.23 & 9.60 & 0.015 \\
\hline Forbs & $\begin{array}{c}-3.04 \\
( \pm 6.34)\end{array}$ & $\begin{array}{c}5.76 \\
( \pm 3.09)\end{array}$ & 1.59 & 0.17 & 3.02 & 7.79 & 0.024 \\
\hline $\mathrm{C}_{3}$ grasses & $\begin{array}{c}-1.44 \\
( \pm 3.32)\end{array}$ & $\begin{array}{c}9.48 \\
( \pm 21.76)\end{array}$ & 0.63 & -0.64 & 1.90 & 1.23 & 0.300 \\
\hline
\end{tabular}




\begin{tabular}{|c|c|c|c|c|c|c|c|}
\hline $\mathrm{C}_{4}$ grasses & $\begin{array}{c}-1.32 \\
( \pm 6.83)\end{array}$ & $\begin{array}{c}1.64 \\
( \pm 3.34)\end{array}$ & 0.50 & -0.76 & 1.76 & 0.76 & 0.409 \\
\hline Sedges & $\begin{array}{c}9.88 \\
( \pm 18.54)\end{array}$ & $\begin{array}{c}-0.16 \\
( \pm 13.27)\end{array}$ & -0.56 & -1.83 & 0.70 & 0.97 & 0.354 \\
\hline Shrubs & $\begin{array}{c}-6.92 \\
( \pm 10.85)\end{array}$ & $\begin{array}{c}1.88 \\
( \pm 1.84)\end{array}$ & 1.02 & -0.30 & 2.34 & 3.20 & 0.112 \\
\hline Ferns & $\begin{array}{c}-5.6 \\
( \pm 10.92)\end{array}$ & $\begin{array}{c}0 \\
( \pm 0)\end{array}$ & 0.65 & -0.62 & 1.93 & 1.31 & 0.285 \\
\hline Trees & $\begin{array}{c}1.36 \\
( \pm 2.91)\end{array}$ & $\begin{array}{c}1.68 \\
( \pm 6.38)\end{array}$ & 0.06 & -1.18 & 1.30 & 0.01 & 0.921 \\
\hline Legume & $\begin{array}{c}-0.12 \\
( \pm 0.27)\end{array}$ & $\begin{array}{c}0.56 \\
( \pm 1.53)\end{array}$ & 0.56 & -0.71 & 1.82 & 0.96 & 0.357 \\
\hline Vines & $\begin{array}{c}-1.04 \\
( \pm 2.44)\end{array}$ & $\begin{array}{c}0 \\
( \pm 0)\end{array}$ & 0.53 & -0.73 & 1.79 & 0.91 & 0.368 \\
\hline
\end{tabular}

Table 3. Process-only trends differences (mean \pm SD) for pre- to post-treatment ecological group measures at Quincy Bluff and Wetlands Natural Area. Bias-adjusted effect size, $95 \%$ confidence interval of effect size, and $F$-values and probabilities for analysis-of-variance (ANOVA) tests are reported. ANOVA models tested main effects of the structural manipulation treatment $(n=12)$ against the control $(n=10)$. Significance values of tests are indicated in bold at $P<0.05$, whereas marginal significance values $(P<0.10)$ are in italics.

\begin{tabular}{|c|c|c|c|c|c|c|c|}
\hline \multirow[t]{2}{*}{ Ecological group } & \multirow{2}{*}{$\begin{array}{l}\text { Control } \\
\text { plot }\end{array}$} & \multirow{2}{*}{$\begin{array}{l}\text { Treatment } \\
\text { plot }\end{array}$} & \multirow{2}{*}{$\begin{array}{l}\text { Effect } \\
\text { size }\end{array}$} & \multicolumn{2}{|c|}{$95 \% \mathrm{CI}$} & \multicolumn{2}{|c|}{ ANOVA } \\
\hline & & & & Lower & Upper & $F$ & $P$ \\
\hline Canopy intercept & $\begin{array}{c}-0.04 \\
( \pm 24.25)\end{array}$ & $\begin{array}{c}-8.30 \\
( \pm 20.52)\end{array}$ & -0.36 & -1.35 & 0.62 & 0.61 & 0.444 \\
\hline Species richness & $\begin{array}{c}-1.40 \\
( \pm 1.67)\end{array}$ & $\begin{array}{c}-2.15 \\
( \pm 3.70)\end{array}$ & -0.21 & -1.19 & 0.77 & 0.19 & 0.667 \\
\hline Diversity & $\begin{array}{c}-0.76 \\
( \pm 0.58)\end{array}$ & $\begin{array}{c}-0.47 \\
( \pm 1.14)\end{array}$ & 0.26 & -0.72 & 1.24 & 0.29 & 0.597 \\
\hline Evenness & $\begin{array}{c}-0.22 \\
( \pm 0.20)\end{array}$ & $\begin{array}{c}-0.10 \\
( \pm 0.33)\end{array}$ & 0.37 & -0.61 & 1.36 & 0.60 & 0.446 \\
\hline Modal savanna & $\begin{array}{c}-0.48 \\
( \pm 4.19)\end{array}$ & $\begin{array}{c}2.06 \\
( \pm 10.84)\end{array}$ & 0.25 & -0.74 & 1.23 & 0.26 & 0.616 \\
\hline $\begin{array}{l}\text { Modal southern } \\
\text { forest }\end{array}$ & $\begin{array}{c}7.32 \\
( \pm 16.29)\end{array}$ & $\begin{array}{c}14.07 \\
( \pm 20.26)\end{array}$ & 0.33 & -0.65 & 1.32 & 0.63 & 0.500 \\
\hline $\begin{array}{l}\text { Modal northern } \\
\text { forest }\end{array}$ & $\begin{array}{c}1.72 \\
( \pm 0.99)\end{array}$ & $\begin{array}{c}-1.41 \\
( \pm 4.13)\end{array}$ & -0.80 & -1.81 & 0.20 & 0.43 & 0.111 \\
\hline
\end{tabular}




\begin{tabular}{|c|c|c|c|c|c|c|c|}
\hline Modal grassland & $\begin{array}{c}-9.08 \\
( \pm 8.77)\end{array}$ & $\begin{array}{c}-1.07 \\
( \pm 5.03)\end{array}$ & 1.32 & 0.28 & 2.37 & 7.40 & 0.012 \\
\hline Forbs & $\begin{array}{c}-3.04 \\
( \pm 6.34)\end{array}$ & $\begin{array}{c}3.32 \\
( \pm 4.23)\end{array}$ & 1.32 & 0.27 & 2.36 & 7.43 & 0.012 \\
\hline $\mathrm{C}_{3}$ grasses & $\begin{array}{c}-1.44 \\
( \pm 3.32)\end{array}$ & $\begin{array}{c}-0.85 \\
( \pm 3.63)\end{array}$ & 0.16 & -0.82 & 1.14 & 0.11 & 0.745 \\
\hline $\mathrm{C}_{4}$ grasses & $\begin{array}{c}-1.32 \\
( \pm 6.83)\end{array}$ & $\begin{array}{c}0.21 \\
( \pm 0.46)\end{array}$ & 0.51 & -0.48 & 1.50 & 1.13 & 0.299 \\
\hline Sedges & $\begin{array}{c}9.88 \\
( \pm 18.54)\end{array}$ & $\begin{array}{c}15.96 \\
( \pm 16.08)\end{array}$ & 0.36 & -0.63 & 1.34 & 0.54 & 0.470 \\
\hline Shrubs & $\begin{array}{c}-6.92 \\
( \pm 10.85)\end{array}$ & $\begin{array}{c}-4.5 \\
( \pm 13.01)\end{array}$ & 0.18 & -0.80 & 1.17 & 0.15 & 0.706 \\
\hline Ferns & $\begin{array}{c}-5.6 \\
( \pm 10.92)\end{array}$ & $\begin{array}{c}-1.87 \\
( \pm 6.27)\end{array}$ & 0.49 & -0.49 & 1.48 & 1.05 & 0.317 \\
\hline Trees & $\begin{array}{c}1.36 \\
( \pm 2.91)\end{array}$ & $\begin{array}{c}-5.62 \\
( \pm 6.10)\end{array}$ & -1.19 & -2.22 & -0.16 & 6.06 & 0.022 \\
\hline Legumes & $\begin{array}{c}-0.12 \\
( \pm 0.27)\end{array}$ & $\begin{array}{c}6.47 \\
( \pm 9.82)\end{array}$ & 0.71 & -0.29 & 1.71 & 2.18 & 0.153 \\
\hline Vines & $\begin{array}{c}-1.04 \\
( \pm 2.44)\end{array}$ & $\begin{array}{c}5.66 \\
( \pm 9.95)\end{array}$ & 0.71 & -0.29 & 1.71 & 2.17 & 0.154 \\
\hline
\end{tabular}

\section{Process-only}

Unlike the structural manipulation approach, the process-only treatments did not result in significant changes in canopy intercept $\left(d_{j}=-0.36, F_{1,23}=0.61, P\right.$ $=0.444$; Table 3$)$. Species richness $\left(d_{j}=-0.21, F_{1,23}=\right.$ $0.19, P=0.667)$, diversity $\left(d_{j}=0.26, F_{1,23}=0.29, P=\right.$ $0.597)$, and evenness $\left(d_{j}=0.37, F_{1,23}=0.60, P=\right.$ $0.446)$ also did not vary between treatment periods. Although canopy and diversity measures did not change, increases in forb cover $\left(d_{j}=1.59, F_{1,23}=7.43\right.$, $P=0.012$ ) similar to those resulting from the structural manipulation approach were evident in process-only treatments. The principal increasing forb for process-only treatments was whorled loosestrife (Lysimachia quadrifolia). An additional observed functional response was the decrease in the amount of cover provided by understory trees $<1 \mathrm{~m}$ in height $\left(d_{j}\right.$ $\left.=-1.19, F_{1,23}=6.06, P=0.022\right)$, which we attributed to oak seedling mortality caused by repeated fire. Process-only treatments also incurred positive, albeit nonsignificant, responses for legume groups $\left(d_{j}=0.71\right.$, $\left.F_{1,23}=2.18, P=0.153\right)$ and vines $\left(d_{j}=0.71, F_{1,23}=\right.$
2.17, $P=0.154)$, due principally to increases in Amphicarpaea bracteata or hog-peanut, a modal southern forest leguminous vine (Appendix 1). Legume species typically associated with oak barrens did not appear to respond to current process-only treatments. Although modal grassland species responded significantly $\left(d_{j}=1.32, F_{1,23}=7.49, P=\right.$ 0.012 ) to process-only treatments, no net gain in modal grassland cover was evident within treatment plots. Instead, significance appeared to be caused mainly by decreases in modal grassland cover at control sites. Modal savanna, southern forest, and northern forest groups failed to show significant responses for process-only treatments. Given that only Quincy received process-only treatments, site effects cannot be ruled out.

\section{DISCUSSION}

\section{Process-only or structural manipulation?}

Because savanna specialists are dependent on or most 
advantaged at particular light or canopy levels (Bray 1958, Nielsen and Haney 1998, Leach and Givnish 1999), initial efforts to restore savanna communities often focus on the management of overstory structure. The use of prescribed burning alone does not appear to support such efforts for degraded oak barrens. A halfcentury or more of fire suppression may simply be too long a period for current process-only approaches to result in the mortality of large overstory oaks (Fig. 3). It is apparent that managers using process-only approaches have concentrated on fire frequency more than fire intensity. For process-only approaches to be effective, however, high-intensity fires should be considered (King 2000). Low-intensity prescribed fires, based on safety rather than ecology, are not likely to result in the mortality of large overstory stems (Anderson 1982). Even $13 \mathrm{yr}$ of annual prescribed burning of degraded oak barrens in Minnesota caused only limited mortality in larger-diameter oaks that had been recruited since fire cessation (White 1983, Peterson and Reich 2001). Restoration costs, not to mention potential ecological problems such as the loss of seed banks and endangered species, may prohibit the continual treatment of an area using light-intensity prescribed burning without significant responses. In contrast, restoration sites that used structural manipulation showed positive trends in the restoration of savanna structure, diversity, and modal savanna and grassland cover. Consequently, we suggest that structural manipulation be used for future oak barren restoration. Two advantages we see to structural manipulation are (1) the generation of income from the sale of timber (Laubach 2000) and (2) the instant control of the overstory canopy.

Fig. 4. A general conceptual model depicting oak barren dynamics for a 0.25 -ha patch across a 150 -yr period. A vertical belt running from east to west across the center of each quadrat is presented for comparison of vertical structure. Presettlement conditions (A) represent a state of tree-grass coexistence with scattered oak grubs and a graminoid matrix. The cessation of fire, however, led to the recruitment of large even-aged oaks, an understory shrub layer that was not previously present, and the loss of the original ground layer (B). Initial results are shown for the process-only (C) and structural manipulation (D) restoration models.

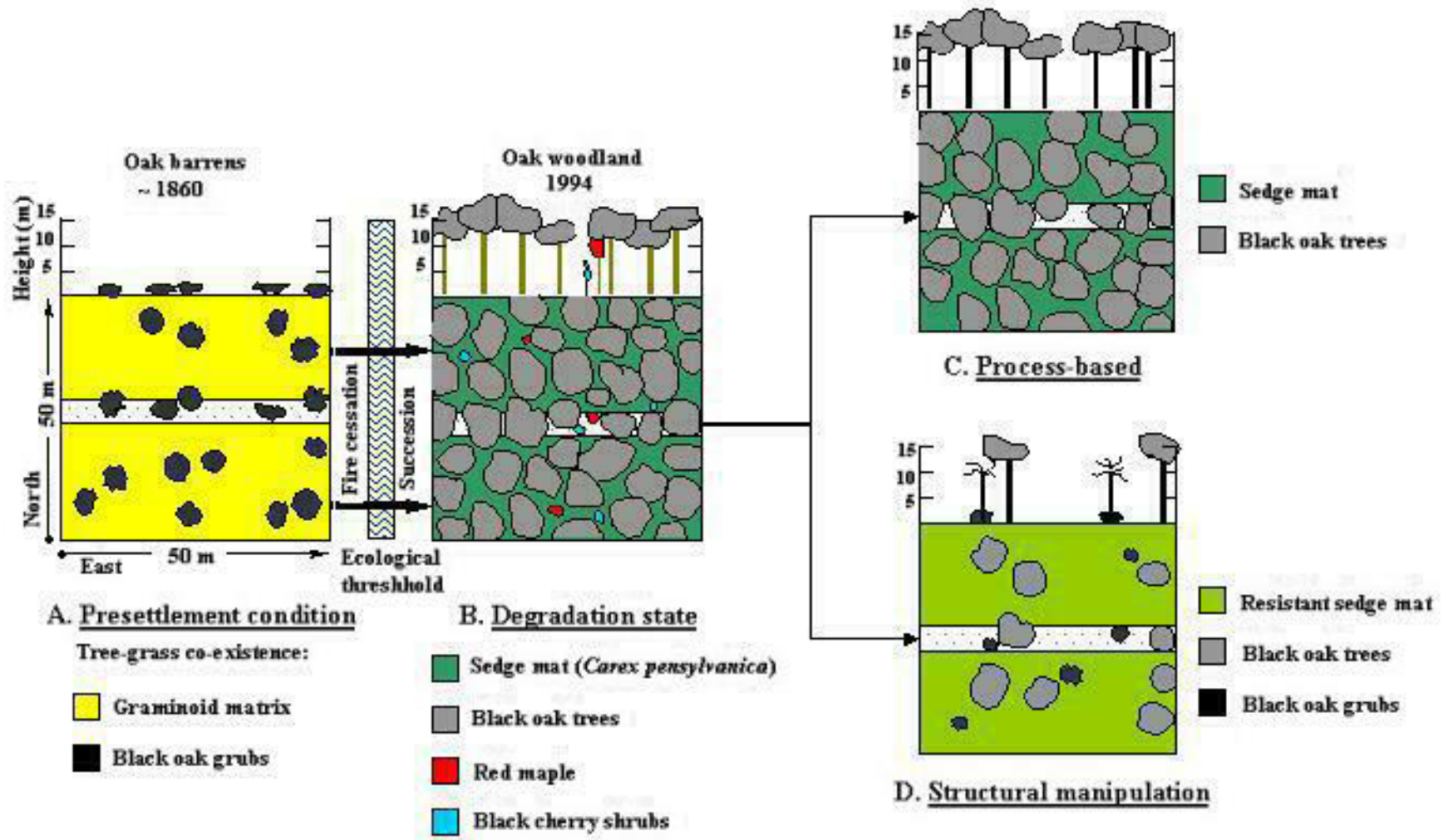




\section{Instantaneous responses or stagnated degradation?}

Although changes were noted during restoration, the magnitudes of the responses observed were much smaller than those recorded previously (Vogl 1964, Holtz and Howell 1983). No significant changes, for example, were evident for $\mathrm{C}_{4}$ grasses, the dominant ground-layer species in most healthy oak barrens. Furthermore, savanna legumes were noticeably absent or failed to respond positively, although a marginal positive response occurred in process-only treatments at Quincy for Amphicarpaea bracteata, a modal southern forest leguminous vine. Many to most of the savanna species have apparently been unable to persist in the ground layer for the length of the degradation that has occurred. Vogl's (1964) speculation that many savanna species would eventually be eliminated following succession, thereby limiting restoration opportunities, appears accurate. That threshold, however, is apparently of unknown temporal scale, because restoration treatments were successful in restoring barrens as late as the early 1980s (Holtz and Howell 1983). In this study, we found evidence for a reduced resilience and alternative steady state. Ground-layer composition continues to be oversimplified for many areas and lacks the rapid responses observed previously (Vogl 1964, Holtz and Howell 1983).

Fig. 3. Before and after photographs of permanent vegetation monitoring plot 137 at Necedah National Wildlife Refuge illustrating the use of the structural manipulation model. Pretreatment conditions in 1994 (A) represent typical degraded oak barrens that have converted to even-aged oak woodland. Post-treatment conditions in 1999 (B) show that, although the plot is now structurally more consistent with the savanna concept, the responses expected based on the results of previous studies are lacking. Domination by Carex pensylvanica can be seen in B.
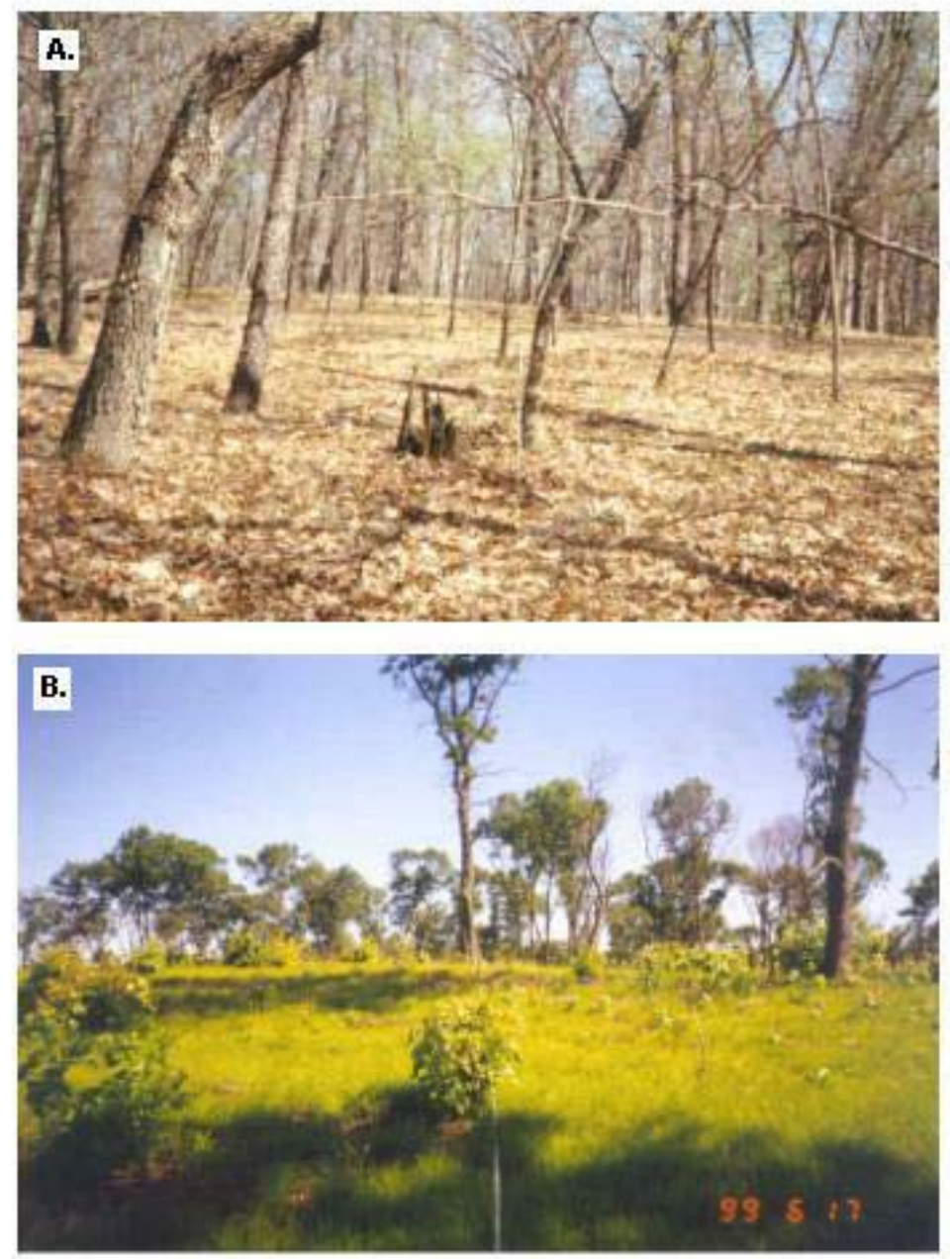
Degraded oak barrens are now frequently dominated by Carex pensylvanica (Abrams et al. 1985; Figs. 3 and 4). The presence of near monocultures of $C$. pensylvanica has previously been used to indicate historical levels of overgrazing and/or the presence of a perched water table (Leach and Givnish 1999). We feel that the conversion of the ground layer to $C$. pensylvanica is just as likely to be a natural phenomenon that occurs in many and perhaps most degraded oak barrens, including areas that have not been grazed historically or that lack a perched water table. Once established, $C$. pensylvanica can greatly alter understory dynamics, driving the system toward a state of arrested succession (Abrams and Dickmann 1983, Abrams et al. 1985). This secondary stable state appears to be a major obstacle for current restoration practices. No longer can we assume that restoration of the process and/or structure will lead to rapid rejuvenation, i.e., instantaneous response, of oak barren ground layers that have been substantially altered.

\section{CONCLUSION}

Although site effects cannot be ruled out, the results of this study imply that process-only approaches, when used under current burning methods, do not cause enough overstory tree mortality. Without canopy mortality, the ground layer is simply unable to recruit light-demanding species, e.g., savanna and prairie species, or induce positive responses from remnant holdovers. Instead, the most effective restoration method appears to be the removal of the overstory structure followed by a program of prescribed burning. Although other forms of disturbance, such as herbivory (Anderson 1982, Abrams 1992) or the infection of healthy oak trees with the oak wilt fungus Ceratocystis fagacearum (Anderson 1982, Pierce 1996, Collada and Haney 1998) could be used to maintain or manage canopy levels, prescribed fire and selective timber removal are easily implemented and more acceptable to the public. Selective timber removal can further offset restoration costs, thereby offering an incentive for restoration of private lands (Laubach 2000). Restoration sites should be chosen based on the presence of holdover species and/or previous disturbances. Without the presence of residual savanna species, domination by alternate steady states is likely, and investment in reseeding may be necessary. Sites that have not been completely converted to $C$. pensylvanica should be of high priority. Important questions that need to be addressed to further understand restoration processes and mechanisms in oak barrens are (1) will sedge mats persist through time with continued burning, (2) how successful will holdover clumps or patches be in the invasion of degraded matrices, and (3) can herbicides and scarification applications be used to manage sedge mats?

Responses to this article can be read online at: http://www.consecol.org/vol7/iss2/art10/responses/index.html

\section{Acknowledgments:}

Special thanks go to the Sand County Foundation (SCF) and the Savanna Partnership for their continual support of restoration efforts. Personnel from SCF who have greatly helped include Reed Coleman, Brent Haglund, Brenda Jessen, Laura Kearney, Kevin McAleese, Ann Miller, and Jackie Scott. We also thank Nathan Wetzel for statistical advice and Kari Jensen, James Cook, Dave Board, and Mark S. Boyce for reviewing an early draft of the manuscript. Rich King and Larry Wargowsky (U.S. Fish and Wildlife Service) made field monitoring possible at Necedah National Wildlife Refuge, while Nancy Braker (The Nature Conservancy) helped facilitate work at Quincy Bluff and Wetlands. This project was made possible through the Savanna Partnership with funds from the Department of Defense Legacy Project (1994-1995), the Sand County Foundation (1995-2000), and a MacIntire-Stennis grant (\#WIS04325, 1999).

\section{LITERATURE CITED}

Abrams, M. D. 1992. Fire and the development of oak forests. Bioscience 42:346-353.

Abrams, M. D., and D. I. Dickmann. 1981. Early revegetation of clear-cut and burned jack pine sites in northern lower Michigan. Canadian Journal of Botany 60:946-954.

Abrams, M. D., and D. I. Dickmann. 1983. Response of understory vegetation to fertilization on mature and clearcut jack pine sites in northern lower Michigan. American Midland Naturalist 110:194-200.

Abrams, M. D., D. G. Sprugel, and D. I. Dickmann. 1985. Multiple successional pathways on recently disturbed jack pine sites in Michigan. Forest Ecology and Management 10:31-48.

Albert, D. A. 1994. Regional landscape ecosystems of Michigan, Minnesota, and Wisconsin: a working map and classification. U.S. Forest Service General Technical Report 


\section{NC-178.}

Anderson, R. C. 1982. An evolutionary model summarizing the roles of fire, climate and grazing animals in the origin and maintenance of grasslands: an end paper. Pages 297-308 in J. R. Estes, R. J. Tyrl, and J. N. Brunken, editors. Grasses and grasslands: systematics and ecology. University of Oklahoma Press, Norman, Oklahoma, USA.

Bauer, M. E. 1943. The statistical analysis of chaparral and other plant communities by means of transect samples. Ecology 24:45-60.

Bonnicksen, T. M., and E. C. Stone. 1985. Restoring naturalness to national parks. Environmental Management 9:479-486.

Bowles, M. L., and J. L. McBride. 1998. Vegetation composition, structure and chronological change in a decadent Midwestern North American savanna remnant. Natural Areas Journal 18:14-27.

Bray, J. R. 1958. The distribution of savanna species in relation to light intensity. Canadian Journal of Botany 36:671-681.

Canfield, R. H. 1941. Application of the line intercept method in sampling range vegetation. Journal of Forestry 39:388-394.

Collada, A. E., and A. Haney. 1998. Vegetation changes associated with oak wilt. Transactions of the Wisconsin Academy of Sciences, Arts and Letters 86:35-46.

Curtis, J. T. 1959. The vegetation of Wisconsin: an ordination of plant communities. University of Wisconsin Press, Madison, Wisconsin, USA.

Gleason, H. A., and A. Cronquist. 1991. Manual of vascular plants of northeastern United States and adjacent Canada. Van Norstrand, Princeton, New Jersey, USA.

Gram, W. K., V. L. Sork, R. J. Marquis, R. B. Renken, R. L. Clawson, J. Faaborg, D. K. Fantz, J. L. Corff, J. Lill, and P. A. Porneluzi. 2001. Evaluating the effects of ecosystem management: a case study in a Missouri Ozark forest. Ecological Applications 11:1667-1679.

Gundlach, H. F., R. R. Gilbertson, R. M. Johannes, and T. A. Meyer III. 1991. Soil survey of Juneau County, Wisconsin. U.S. Department of Agriculture, Soil Conservation Service, Washington, D.C., USA.

Haney, A., and S. I. Apfelbaum. 1994. Measuring changes in oak savannas: a review and recommendations for a monitoring protocol. Pages 253-257 in J. S. Fralish, R. C. Anderson, J. E. Ebinger, and R. Szafoni, editors. Proceedings of the North American Conference on Savannas and Barrens. Illinois State University, Normal, Illinois, USA.

Hedges, L., and I. Olkin. 1985. Statistical methods for meta-analysis. Academic Press, New York, New York, USA.

Heikens, A. L., and P. A. Robertson. 1994. Barrens of the Midwest: a review of the literature. Castanea 59:184-194.

Holtz, S. L., and E. A. Howell. 1983. Restoration of grassland in a degraded woods using the management techniques of cutting and burning. Proceedings of the Eighth North American Prairie Conference 8:124-129.

Hurlbert, S. H. 1984. Pseudoreplication and the design of ecological field studies. Ecological Monographs 54:187211.

Jakel, D. E. 1980. Soil survey of Adams County, Wisconsin. U.S. Department of Agriculture, Soil Conservation Service, Washington, D.C., USA.

King, R. 2000. Effects of single burn events on degraded oak savanna. Ecological Restoration 18:228-233.

Laubach, S. A. 2000. Ecological and economic factors in oak savanna/woodland restorations: vegetation, bird species, and financial considerations for land managers. Thesis. University of Wisconsin-Madison, Madison, Wisconsin, USA.

Leach, M. K., and T. J. Givnish. 1999. Gradients in the compositions, structure and diversity of remnant oak savanna in southern Wisconsin. Ecological Monographs 69:353-374.

Magurran, A. 1988. Ecological diversity and its measurement. Princeton University Press, Princeton, New Jersey, USA.

McPherson, G. R. 1997. Ecology and management of North American savannas. University of Arizona Press, Tucson, Arizona, USA.

Moore, M. M., W. W. Covington, and P. Z. Fulé. 1999. Reference conditions and ecological restoration: a southwestern ponderosa pine perspective. Ecological Applications 9:1266-1277.

Nielsen, S. E., and A. Haney. 1998. Gradient responses for understory species in a bracken-grassland and northern-dry forest ecosystem of Northeast Wisconsin. Transactions of the Wisconsin Academy of Sciences, Arts and Letters 86:149-166.

Nuzzo, V. 1986. Extent and status of Midwestern oak savanna: presettlement and 1985. Natural Areas Journal 6:6-36.

Parsons, D. J., D. M. Graber, J. K. Agee, and J. W. van Wagtendonk. 1986. Natural fire management in national parks. Environmental Management 10:21-24.

Pierce, A. M. 1996. Herbaceous understory response to prescribed burning and oak wilt in degraded oak savanna. 
Thesis. University of Wisconsin-Stevens Point, Stevens Point, Wisconsin, USA.

Peterson, D. W., and P. B. Reich. 2001. Prescribed fire in oak savanna: fire frequency effects on stand structure and dynamics. Ecological Applications 11:914-927.

Shannon, C. E., and W. Weaver. 1949. The mathematical theory of communication. University of Illinois Press, Urbana, Illinois, USA.

Stephenson, N. L. 1999. Reference conditions for giant sequoia forest restoration: structure, process, and precision. Ecological Applications 9:1253-1265.

Underwood, A. J. 1997. Experiments in ecology: their logical design and interpretation using analysis of variance. Cambridge University Press, Cambridge, UK.

U.S. Fish and Wildlife Service. 2000. Necedah National Wildlife Refuge Draft Comprehensive Conservation Plan. U.S. Department of the Interior, Necedah, Wisconsin, USA.

Vogl, R. J. 1964. Vegetation history of Crex Meadows, a prairie savanna in northwestern Wisconsin. American Midland Naturalist 72:157-175.

Wetter, M. A., T. S. Cochrane, M. R. Black, H. H. Iltis, and P. E. Berry. 2001. Checklist of the vascular plants of Wisconsin. Technical Bulletin Number 192. Department of Natural Resources, Madison, Wisconsin, USA.

Werner, P. A., B. H. Walker, and P. A. Scott. 1990. Introduction. Journal of Biogeography 17:343-344.

White, A. S. 1983. The effects of thirteen years of annual prescribed burning on a Quercus ellipsoidalis community in Minnesota. Ecology 64:1081-1085. 